often related that the Carabidae in particular fas. cinated him. It was not just because they varied so much in colour, nor was it the mechanism of this variation that attracted him; the great question was 'why' did they vary. It is this theme that runs like a thread through all his writings.

At Göttingen he had been awarded the coveted Summa cum Laude in botany and zoology and afterwards obtained a diploma in teaching - a fact which his own daughters learnt later to appreciate. A year of voluntary military training was followed by appointments in the grammar school at Münden and at the School of Agriculture at Hildesheim. In 1891 he was able at last to marry the girl who had waited for him since both were in their 'teens; their marriage could not have been happier.

At the age of thirty-two, already with wide experience behind him, Jordan seemed set for a distinguished academic career. It was then that chance brought him in contact with Ernst Hartert, who had just been appointed by Walter (later Lord) Rothschild to be director of the Zoological Museum which he had formed at Tring-in two small cottages. Jordan's first task on arrival at Tring was to reduce to order the immense but chaotic collection of beetles (the Lepidoptera were olready in better shape) stored in various parts of Tring, without proper working conditions or even a microscope. It was just what he wanted, a marvellous enforced exercise in the study of geographical variation, and any odd corner served as a bench. However, it soon became apparent that not even his devoted labours, carried far into the night, could cope with both the Coleoptera and the Lepidoptera at Tring, and before long the collection of the former was abandoned, except the Anthribiidae, a group of weevil-like beetles the complexity of which never ceased to fascinate Jordan, and on which alone he published more than eighty papers.

Meanwhile, Walter Rothschild, who was deeply involved in a systematic revision of the swallow-tail butterflies of the Oriental Region, enlisted Jordan's help. In a long introductory passage, Jordan (1895) proved himself some fifty years ahead of his time : he clearly appreciated the importance of populations as basic taxons, distinguished between individual, environmental and geographical variation, according the last firmly and precisely subspecific rank and applying a trinomial system of nomenclature exclusively to it. Here, too, he recognized the importance of the type system. During the next ten or twelve years other similar monographs appeared, on the hawk-moths, on the American swallow-tails, on the genus Charaxes, on certain families of emperor moths. These impressive monographs were built soundly on the most painstaking attention to detail, whether concerned with morphological minutiæ, distribution or bibliography; all the essential evidence available at the time, and a very great deal of entirely new and original matter, were welded together concisely in masterly fashion. However, this systematic work was by no means an end in itself.

Simultaneously, Jordan was publishing on pure morphology, on sense organs, on mimicry among butterflies and its significance for evolution, on geographical variation in relation to evolution, on 'mechanical' selection, and so on. 'Throughout his writings there is the constant theme that experimental biology and systematics are interdependent; neither can be complete, or even wholly dependable, without the other. The study of systematics was to him a means for proving the truth of evolution, and, as another writer has said, he "exerted an influence on the development of systematics and on evolutionary thought that cannot be over-estimated". It is quite possible, however, that his unpublished influence was equally great, for no one could have been more generous than Jordan in the inspiring help he gave so freely to his innumerable correspondents in all parts of the world.

At the age of seventy-four, Jordan made his first really ambitious collecting expedition, to South West Africa. When well over eighty, he remarked that it was time he started on his catalogue of fleas, a task he felt he owed to Charles Rothschild. The story of their fruitful co-operation has been told elsewhere; it was left to Miriam Rothschild, one of his most ardent disciples and admirers, to undertake this task, with the help of the Trustees of the British Museum. On his ninety-fourth birthday the Royal Entomological Society of London published a special volume in his honour, an event unique in its history and more significant an indication of the esteem in which he was held than anything these few words can convey. My own lasting impression is one of effervescent enthusiasm, intense interest in discovery and in the future, of the unexpected wit with which he would enliven a dull discussion, of his unfailing, unstinted help and kindliness, and of the fruitfulness of his long and happy life. He died on January 12, in his ninety-eighth year. N. D. RILEY

\section{Dr. J. Travis Jenkins, O.B.E.}

Dr. James Travis Jenkins died on January 12, at his home, Henbant Hall, Capel Dewi, Llandyssul, Cardiganshire. Born in 1876, the son of a schoolmaster, he attended school first at Pontardawe, Glamorgan, and then at the Merchant Venturers' School, Bristol. Afterwards he attended the University Colleges of Aberystwyth and Cardiff, and in 1897 graduated B.Sc. of the University of Wales. Only three years afterwards (1900) he was awarded the doctor of science degree of the University of Wales for a thesis on the anatomy of the oyster. His early preoccupation with marine zoology, and particularly with its economic aspects, was also shown in his work at Kiel, where a year or two later he was awarded a doctorate of philosophy.

In 1904 Jenkins was appointed superintendent of the Lancashire and Western Sea Fisheries Joint Committee, and this post he held until his retirement in 1946, except for a short period during 1908-10, when he was seconded to the Bengal Government to investigate and organize the fisheries of the Bay of Bengal. On Indian fishes and fisheries he published a number of papers, some under the seal of the Bengal Government, others in the Records of the Indian Museum. He retained his interest in the subject in later years, and even so late as 1938 an article by him on "The Fisheries of Bengal-Can they be Developed and Improved?" appeared in Current Science.

As superintendent of the Lancashire and Western Sea Fisheries Joint Committee, Jenkins was responsible for a long series of quarterly reports dealing with the mussel, cockle and other fisheries of the Com. mittee's district and with the various laws and regulations relating to these. In addition to his scientific qualifications, he was admitted a barrister of Gray's Inn in 1910. He acted for many years as honorary secretary of the Association of Sea Fisheries Committees of England and Wales. His work for 
the inshore fisheries was recognized by his appoint. ment as O.B.E. in 1941.

He will be chiefly remembered for a series of books relating to fisheries and fishes : "The Sea Fisheries" (1920); "A Textbook of Oceanography" (1921); "A History of the Whale Fisheries" (1921); "The Herring and the Herring Fisheries" (1927); "Whales and Modern Whaling" (1932); and, best known of all, "The Fishes of the British Isles", the first edition of which appeared in 1925 and the second in 1936 . He had always a keen interest in the historical and literary aspects of the fishing industries, and his last publication, issued in 1948 by the Society for the Bibliography of Natural History, was a comprehensive "Bibliography of the Whale Fisheries".

Jenkins was for many years a member of the Council of the National Museum of Wales. I recall with appreciation not only his many donations of specimens to the Zoology Department of the Museum but also his companionship both abroad and on collecting trips on board the Lancashire and Western Committee's steamer, the S.S. James Fletcher.

Colin MATHESON

\section{Mrs. E. W. Sexton}

The death occurred on February 18, at the home of her son at Alfriston in Sussex, of Mrs. Alice Wilkins Sexton, at the age of ninety. Although without scientific academic training, Mrs. Sexton (known under her adopted initials of 'E. W.') became an authority of international repute on Crustacea. Living at Plymouth, where her husband was a. dentist, she began to work at the Laboratory of the Marine Biological Association at the beginning of this century under the guidance of the late Dr. E. J. Allen, for whom she made beautiful drawings of polychrtes. Later, she was appointed a member of the scientific staff of the Plymouth Laboratory.

She was most noted for her systematic work on amphipods, and for the detailed study she rnade of the growth, moulting, intersexes and genetics of Gammarus. In the latter she concentrated especially on eye colour. The names of her speries, Gammarus chevreuxi and $G$. zaddachi, are well known to biologists. All her publications were accompanied by examples of her meticulously careful and accurate drawings, which were at times astonishing in their detail.

A woman of remarkable vitality, she had many interests, notably the cultivation of unusual plants from many countries. Until she had to leave Plymouth in 1957 owing to failing eyesight her hospitable home, with its many and varied treasures, had been open to a very wide circle of friends from Britain and elsewhere.

Mrs. Sexton was a Fellow of the Linnean Society. She leaves a married son, Col. F. B. W. Sexton; her daughter Mary, who was librarian at the Plymouth Laboratory, died in 1951.

\section{NEWS and VIEWS}

Pharmacology at Oxford: Prof. J. H. Burn, F.R.S. Joshua Harold BuRN has been professor of pharmacology in Oxford since 1937. His restless energy has built the most active pharmacological department in the world. Many of his students have learned to do accurate experiments and to write clear papers. He has attracted workers from many countries, who came to learn the techniques of which he is master. He is retiring at the age of sixty-seven, but shows no sign that his mind is less active than it was. He was educated at Barnard Castle School, University of Cambridge, and Guy's Hospital, London. Like many others, he derived inspiration from $H . H$. Dale, with whom he worked before the First World War at the Wellcome Physiological Research Laboratories, and then, after service in the Royal Engineers, in the National Institute for Medical Research. In 1926 he became professor of pharmacology in the College of the Pharmaceutical Society and director of a laboratory which undertook the biological standardization of drugs on a large scale. He wrote a book which laid the foundations of accurate methods of assay, and he has written at least half a dozen other books on various aspects of pharmacology, and large numbers of scientific papers, lectures, reviews, editorials and reports of various kinds. He makes up his mind and puts his thoughts on paper without trouble or delay, and has provided a very potent stimulus to the development of pharmacology. His work has been concerned with all classes of drug, but has been especially important when he has used pharmacological methods to solve physiological problems.
Prof. W. D. M. Paton, F.R.S.

William Drummond Macdonald Paton succeeds Burn as professor of pharmacology at Oxford. He was born in 1917 and educated at Repton School, the University of Oxford, and University College Hospital, London. Ho joined the staff of the National Institute for Medical Research in 1944. During his eight years there he made his name by two outstanding pieces of work. With F. C. MacIntosh he showed that various simple organic bases cause the release of histamine, which disappears from the tissues of animals. It has thus been possible to study not only the mechanisms of release, but also the effects of removing most of the histamine, which are surprisingly small. With E. Zaimis he discovered not only that small doses of decamethonium cause neuromuscular blockade by depolarizing the end plate, but also that hexamethonium blocks transmission through autonomic ganglia. The analysis of the mode of action of these drugs by these two workers became a model for such studies. Hexamethonium was the first drug shown to have a really powerful and specific action on peripheral autonomic ganglia. It has been invaluable as a research tool, but it is best known as the basis of the first really effective treatment for high blood pressure. This was a major advance in therapeutics and led to the award of the Cameron Prize to Paton and Zaimis in 1956. In 1952 Paton went as reader to University College and in 1954 he was appointed to the newly founded chair of pharmacology at the Royal College of Surgeons. 